\title{
Çoklu Çatlayan Lifli Kompozitlerin Birim Şekil Değişiminin Dijital Görüntü Korelasyonu ile Analizi: Parametre Etkilerinin Değerlendirilmesi
}

\author{
Tarık YILDIRIM ${ }^{1}$ \\ Muhammer KESKINATEŞ ${ }^{2}$ \\ Eren GÖDEK ${ }^{3}$ \\ Kamile TOSUN FELEKOĞLU ${ }^{4}$ \\ Burak FELEKOĞLU ${ }^{5}$ \\ Okan ÖNAL ${ }^{6}$
}

ÖZ

Bu çalışmada çekme yüklemesi altında çoklu çatlak davranışı sergileyen lifli kompozitlerin birim şekil değiştirmeleri geleneksel deformasyon ölçer (LVDT) ve dijital görüntü korelasyonu (DIC) yöntemiyle incelenerek kıyaslanmıştır. DIC yönteminde $1 s ̧ 1 \mathrm{k}$ etkisi (kontrollü aydınlatma varlığı), görüntü çözünürlüğü, alt küme boyutu ve adım aralığ1 parametreleri ile iki farklı korelasyon yöntemi dikkate alınarak analizler gerçekleştirilmiştir. Uygun alt küme boyutunun seçilmesi ve görüntülerin kontrollü aydınlatma ile yüksek çözünürlük koşullarında alınması durumunda, DIC analizi sonucu elde edilen birim şekil değiştirme değerleri, LVDT’lerden elde edilen değerler ile örtüşmektedir.

Anahtar Kelimeler: Dijital görüntü korelasyonu, aydınlatma, çözünürlük, alt küme, analiz adım aralığı, korelasyon yöntemleri.

\footnotetext{
Not: Bu yazı

- Yayın Kurulu’na 22 Şubat.2018 günü ulaşmıştır. 22 Nisan 2019 günü yayımlanmak üzere kabul edilmiştir.

- 31 Mart 2020 gününe kadar tartışmaya açıktır.

- https://doi.org/10.18400/tekderg.397681

1 Dokuz Eylül Üniversitesi, Fen Bilimleri Enstitüsü, İzmir - yildirimtarik75@gmail.com https://orcid.org/0000-0002-4184-7932

2 Dokuz Eylül Üniversitesi, Fen Bilimleri Enstitüsü, İzmir - muhammerkeskinates@hotmail.com Karamanoğlu Mehmetbey Üniversitesi, İnşaat Mühendisliği Bölümü, Karaman muhammerkeskinates@kmu.edu.tr - https://orcid.org/0000-0001-8334-3073

3 Hitit Üniversitesi, Teknik Bilimler Meslek Yüksekokulu, İnşaat Teknolojisi Bölümü, Çorum erengodek@hitit.edu.tr - https://orcid.org/0000-0002-3427-2317

4 Dokuz Eylül Üniversitesi, İnşaat Mühendisliği Bölümü, İzmir - kamile.tosun@deu.edu.tr https://orcid.org/0000-0003-2191-7793

5 Dokuz Eylül Üniversitesi, İnşaat Mühendisliği Bölümü, İzmir - burak.felekoglu@deu.edu.tr https://orcid.org/0000-0002-7426-1698

6 Dokuz Eylül Üniversitesi, İnşaat Mühendisliği Bölümü, İzmir - okan.onal@deu.edu.tr https://orcid.org/0000-0002-3089-2711
} 


\section{ABSTRACT \\ Strain Analysis of Multiple Cracking Fiber Reinforced Composites by Digital Image Correlation: Evaluation of Parameter Effects}

In this study, strain of fiber reinforced composites exhibiting multiple cracking under tensile load was compared by using traditional deformation meter (LVDT-Linear Variable Differential Transformer) and digital image correlation (DIC) method.

In the DIC method, analyzes were performed by taking the influence of light (presence of controlled illumination), image resolution, subset size and step size parameters and two different methods of correlation into account. If appropriate subset size is selected, the strain values obtained by DIC analysis corresponded to the values obtained from LVDTs when images are taken under controlled lighting and high resolution conditions.

Keywords: Digital image correlation, illumination, resolution, subset, step size, correlation methods.

\section{GíRiș}

Mühendislik özellikleri geliştirilmiş çimento esaslı kompozitler (Engineered Cementitious Composites-ECC); çimento, puzolan, su, ince agrega $(<200 \mu \mathrm{m})$, az miktarda akışkanlaştırıcı katk1 ve genellikle hacimce $\% 2$ oranında mikro boyutlu polimerik lif içeren bir kompozit türüdür [1]. ECC, gösterdiği çoklu mikro çatlama davranışı sayesinde yalın beton ve çimento esaslı geleneksel lifli kompozitlere kıyasla yük taşıma yeteneğini kaybetmeden daha fazla şekil değiştirebilen düktil bir kompozittir (Şekil 1.1a) [2,3].

ECC, yük altında metallere benzer şekilde ama farklı bir mekanizmayla şekil değiştirme sertleşme davranışı göstermektedir. ECC tasarımında kullanılan mikro-mekanik teoriye göre, yükleme sırasında kompozitte ortaya çıkan çatlakların kararlı olması beklenmektedir [4]. Bu beklentinin sağlanıp sağlanamadığının kontrolü ancak numune çatlak gelişiminin takip edilmesi ve bölgesel olarak ölçülmesi ile belirlenebilir [5]. Ancak deneysel çatlak analizinin bazı güçlükleri bulunmaktadır. ECC'nin çatlak analizinin bütünüyle yapılabilmesinde geleneksel ölçüm yöntemleri (noktasal sensörler, çatlak genişliğini ölçen mikro sensörler vb.) yetersiz kalmaktadır. Bu durumun nedeni numune üzerinde çok sayıda ve mikron mertebesinde çatlakların oluşmasıdır. Şekil 1.1b'de sunulan ECC numunesinde \%1-2-3-4 çekme birim şekil değişimi değerlerinde çekilen çatlaklı kompozit fotoğrafları görüntülenmektedir. Her bir çatlağın yük altındaki genişleme davranışını incelemek, hem ilk çatlağın hem de açılacak yeni çatlakların kesit üzerinde nerede oluşacağı bilinemediğinden numune üzerine çok sayıda sensör yerleştirilmesini gerektirecektir. Böyle bir deney sisteminin kurulması uygulamada oldukça güçtür. Bu durum, çatlak analizinin eş zamanlı ve doğru bir şekilde yapılabilmesi için, geniş bir alanda şekil değiştirmeyi mikron mertebesinde inceleyebilecek bir sistemin gerekliliğini ortaya çıkartmıştır [6].

Son yıllarda, malzeme davranışının karakterizasyonu için dijital görüntü korelasyon (DIC) tekniklerinin kullanımı önemli ölçüde artmıştır. Bu sistem temassız bir şekilde incelenecek tüm alan üzerindeki, yer değiştirme, birim şekil değiştirme ölçümlerini ve çatlak takibini kolay ve hızlı bir şekilde analize imkân vermektedir [7]. 


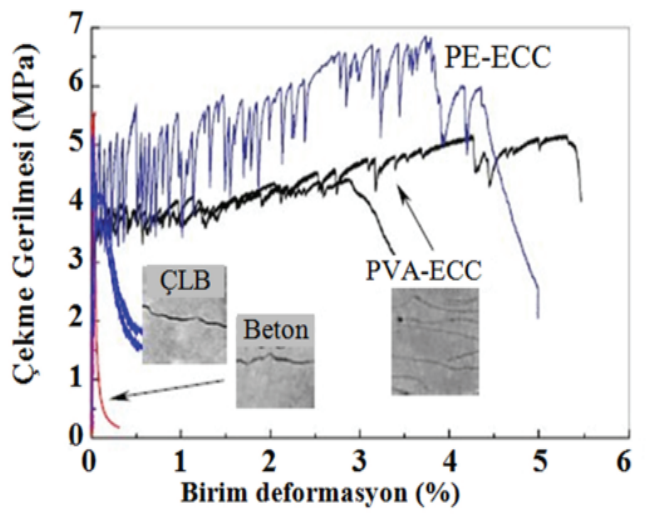

ÇLB: Çelik Lifli beton, PE-ECC: Polietilen lifli çimento esaslı kompozit, PVA-ECC: Polivinil alkol lifli çimento esaslı kompozit

(a)

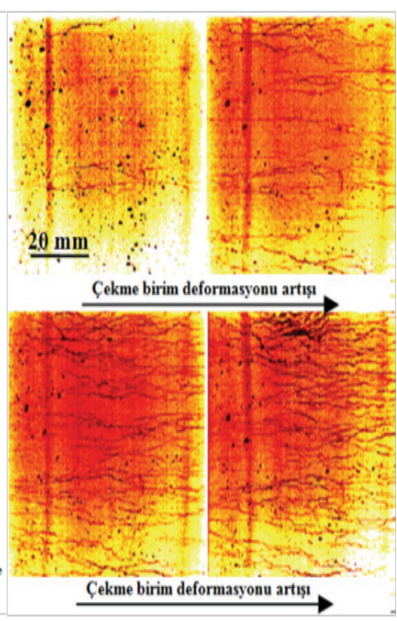

(b)

Şekil 1.1 - a) Bazı kompozit türlerinin çekme birim şekil değiştirme kapasitesinin yalın beton ve çelik lifli betonla klyaslanmast,

b) ECC numunesinde \%1-2-3-4 çekme birim şekil değişimindeki çatlak fotoğrafları [3].

\section{DİJITAL GÖRÜNTÜ KORELASYONU}

Teknolojinin hızlı ilerleyişi ve optik aletlerin geliştirilmesi, endüstri alanında ve özel uygulamalarda temassız ölçüm tekniklerinin yaygın olarak kullanılmasını sağlamıştır. Son yıllarda geliştirilen, düşük maliyetli ve esnek bir çözüm sağlayan DIC yöntemi, otomotiv endüstrisi, malzeme testleri ve tıbbi uygulamalar gibi birçok alanda kullanılmaktadır [8]. DIC; kullanımı kolay, basit optik içeren, titreşimden daha az etkilenen, güvenilir ve tüm malzeme sınıflarına uygulanabilir bir deformasyon ölçüm yöntemidir [9]. Uygun çözünürlüğe sahip olan bir kamera seti, beneklenerek hazırlanmış numune, soğuk 1şık kaynağ1 ve analizde kullanılacak programı içeren bir bilgisayar dijital görüntü korelasyonu yönteminin düzeneğini oluşturur (Şekil 2.1) [10].

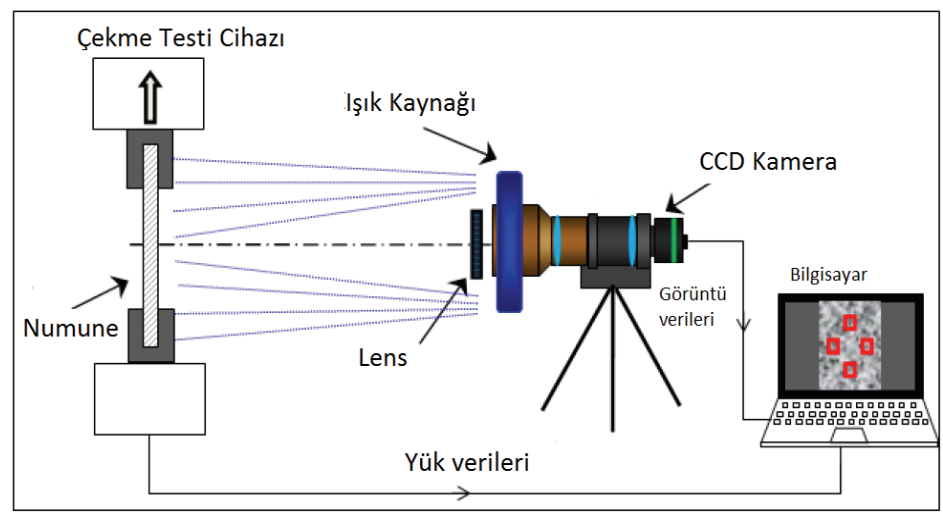

Şekil 2.1 - DIC ile ölçüm yapılırken kullanılan araçlar [10] 
DIC analizi, rastgele benekli desenle kaplanmış numunenin deforme olmadan ve deforme olduktan sonraki iki görüntüsü arasındaki model uyuşması üzerine kuruludur. Buradaki amaç eşleşen görüntü fonksiyonlarının yakalanmasıdır (Şekil 2.2). DIC'nin temel ilkesi, deforme olmamış haldeki numune yüzeyi üzerinde analiz edilecek bölge (region of interest-ROI) içindeki küçük kareler arasında maksimum korelasyonu aramaktır. Bir dizi piksel içeren küçük kare bölüm alt küme, altındaki iki grubun arasındaki mesafe adım aralığı olarak tanımlanır. Alt küme boyutu, yer değiştirme ölçümü için ardışık görüntüler arasında izlenen görüntünün alanını belirler. Adım aralığı ise yer değiştirmeyi tahmin etmek için alt kümenin üzerinde kaydırılması gereken piksel sayısını belirler [9].

Araştırmacılar tarafından korelasyon kriterinin tanımında; normalleştirilmiş çapraz korelasyon, kareler toplamının farkları vb. yöntemler kullanılmıştır [11].

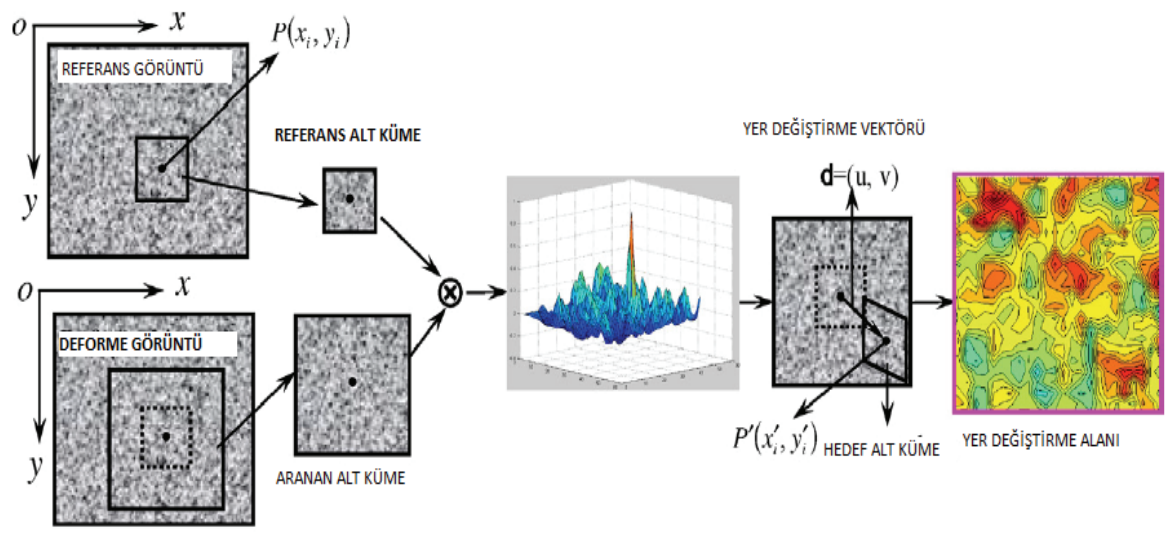

Şekil 2.2 - Referans ve deforme görüntüde alt kümelerin eşlenmesi [11]

DIC analizini etkileyen parametreler şu şekilde sıralanabilir;

1) Düzenek hazırlanırken; numune yüzeyi düz, düzlem dışı şekil değiştirmeler ihmal edilecek kadar küçük (2D), kamera ve numune yüzeyi birbirlerine paralel olmalıdır (Şekil 2.1) [11,12].

2) Elde edilen görüntü üzerindeki piksel sayısı (çözünürlük) analizin doğruluğunu olumlu yönde etkilemektedir. Daha büyük bir alanı ölçmek için, çalışma mesafesi arttırılmalıdır, bu da ölçüm alanındaki efektif çözünürlüğü düşürür [13]. Bu nedenle, analiz edilecek bölge için en yüksek çözünürlügüun elde edileceği en uygun mesafe belirlenmelidir.

3) Elde edilen görüntünün kalitesini etkileyen önemli öğelerden biri aydınlatmadır. Kaliteli bir görüntünün eldesi, mekanik deneyler esnasında numune yüzeyinin tüm alanını kapsayan üniform ve uygun bir aydınlatmanın kullanılması ile mümkün olmaktadır [14]. Uygun bir aydınlatma ve benekleme yapılmasının ortak amacı, dijital görüntüde yüksek kontrastlı düşük gürültülü (noise) benek deseni oluşturmaktır. 
4) Görüntülerin işlenmesi sürecinde analiz sonucunu etkileyen parametrelerin başında alt küme boyutu ve analiz adım aralığı gelmektedir. Alt kümenin temel rolü benekleme desenine bağlı olarak iki bölge arasındaki benzerliği karakterize etmektir. Alt küme seçimi analizin doğruluğu ve zaman açısından önemlidir. Tek bir nokta yerine bir alt kümeyi seçmenin nedeni, kare bir alt kümenin gri seviyesi değerinin tek bir noktayla karşılaştırıldığında daha ayırt edilebilir olmasıdır [15]. Adım aralığının temel rolü ise alt küme taranma sıklığını belirlemektir. Analiz adım aralığ noktayı hesaplamak için alt kümenin dikey ve yatay yönde kaç piksel yer değiştirdiğini tanımlar [14,16]. DIC yönteminde uygun alt küme boyutunu ve analiz adım aralığını belirlemek için kullanılan genel kabul görmüş bir kural yoktur. Bu yüzden söz konusu parametreler uygulamadan uygulamaya değişkenlik göstermektedir. Büyük alt küme boyutu içerisinde fazla desen içerir ve detaylı tarama yapma ihtiyacını azaltmış olur. Çok küçük alt küme boyutu ise yetersiz sayıda özellik içerir ve görüntü içerisinde diğer alt kümelerden program tarafından ayırt edilmesinde güçlükler yaşanır. Bu nedenle küçük alt küme boyutu güvenilir bir korelasyon sağlamayabilir [17]. Son yıllarda yapılan çalışmalarda, alt küme boyutları analiz açısından ideal alt küme boyutu olarak 31x31 - 51x51 piksel kümeleri arasında önerilmektedir $[15,17,18]$. Uygun bir analiz adım aralığı seçimi ise sınırlı sayıdaki ölçüm noktası için gerçeğe yakın şekil değişimlerin hesabına imkân verir. Küçük analiz adım aralığı da çok sayıda ölçüm noktasına erişilmesini sağlar, ancak elde edilen şekil değişimi bölgesinde hataların artmasına neden olur. Yapılan bir çalışmada, şekil değişimi değişkenliğini azaltmak için analiz adım aralığının en az 1 piksel ile başlaması ve alt küme boyutunun yarısından küçük olması önerilir [16]. Analiz adım aralığı ne kadar küçükse, yer değiştirme verisi o kadar çok olacağı için korelasyonun hesaplama süresi de artacaktır. Bu nedenle en uygun analiz adımı seçimi önerilmektedir [16,19].

5) DIC'de şekil değişimi analizi için kullanılan korelasyon yöntemleri, referans ve deforme olmuş görüntü arasındaki benzerliklerin hesaplanmasında oldukça kritik bir öneme sahiptir. Araştırmacılar tarafından korelasyon kriteri için kare farklarının toplamı (sum of squared differences-SSD), normalleştirilmiş kare farklarının toplamı (normalized sum of squared differences-NSSD) ve normalleştirilmiş çapraz korelasyon (normalized cross-correlation-NCC) gibi çeşitli hesaplamalar önerilmiştir $[12,20]$.

Bu çalışma kapsamında, DIC analizinin başarısında önemli rolü olan ve yukarıda sözü edilen parametrelerin ECC'nin birim şekil değiştirmesinin ölçümü için optimizasyonu amaçlanmıştır. Bu kapsamda; aydınlatma, çözünürlük, alt küme boyutu ve analiz adım aralığ1 parametreleri ile korelasyon yöntemi değiştirilerek elde edilen sonuçların doğruluğu geleneksel deformasyon ölçme tekniği ile (LVDT ile elde edilen mekanik verilerle) kıyaslanmıştır. Böylece, bu makale kapsamında dâhil olmayan (bir sonraki aşamada gerçekleştirilecek) çoklu çatlak analizi için gerekli lokal birim şekil değişimlerinin sağlıklı bir şekilde elde edilmesi amaçlanmıştır. 


\section{DENEYSEL ÇALIŞMALAR}

\subsection{Kullanılan Malzemeler ve Deneysel Yöntem}

ECC üretiminde, CEM I 42.5 R tipi Portland çimentosu, yüksek firın cürufu (YFC), yüksek çekme dayanımlı polipropilen lif (HTPP) ve polikarboksilat esaslı bir su azaltıcı/süper akışkanlaştırıcı kimyasal katkı kullanılmıştır. Üretilen taze haldeki lifli matris ile Japon İnşaat Mühendisleri Topluluğu'nun yüksek performanslı lifli kompozitler için önerdiği boyutlarda kemik şeklindeki çekme numuneleri hazırlanmıştır [21]. Hazırlanan numunelerin karışım oranları Tablo 3.1'de sunulmuştur. DIC yöntemi kapsamında araştırılması planlanan parametrelere bağlı olarak numunelerin hazırlanma sistematiği ve numune boyutları Şekil 3.1'de gösterilmiştir.

Tablo 3.1 - Üretilen kompozitlerin karışım oranları.

\begin{tabular}{|c|c|c|c|c|c|}
\hline Bileşenler & Çimento & YFC & Su & $\begin{array}{c}\text { Süper } \\
\text { akışkanlaştırıcı }\end{array}$ & $\begin{array}{c}\text { HTPP } \\
\text { lif }\end{array}$ \\
\hline Ağırlık $\left(\mathrm{kg} / \mathrm{m}^{3}\right)$ & 424 & 1059 & 466 & 2 & 18 \\
\hline
\end{tabular}
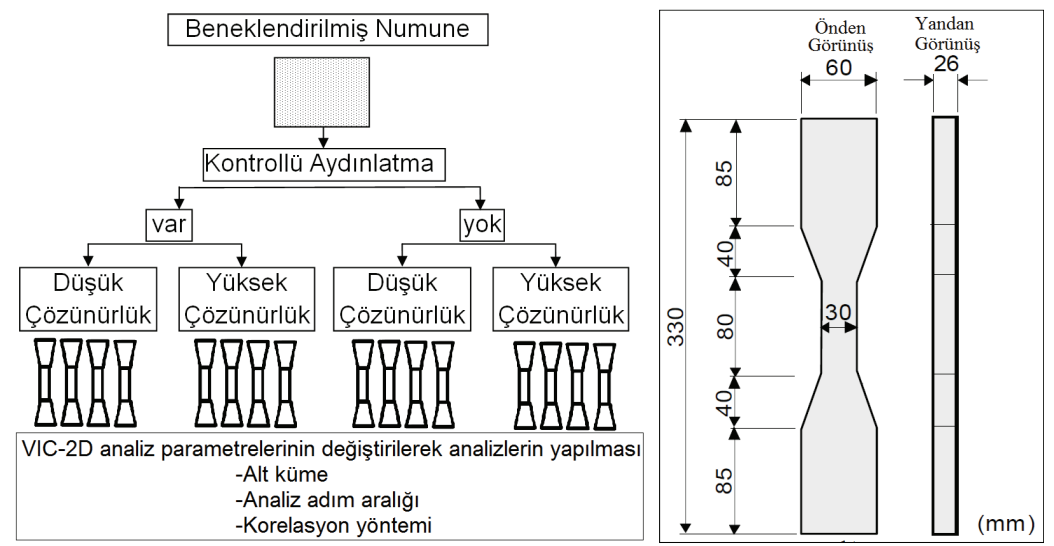

Şekil 3.1 - DIC yöntemi uygulama sistematiği ve numune boyutlart

Beneklendirme ile ilgili belli bir standart henüz bulunmamaktadır. Ön çalışmalar sonucunda elde edilen benek desenlerine göre bu çalışmanın nihai benek deseni belirlenmiştir. Arka planı beyaz boya ile hazırlanmış numuneler üzerine siyah sprey boya ile $115 \mathrm{~cm}$ mesafeden karşı yüzeye doğru 5 sn numunenin bir yanından diğer 5 sn öteki yanından olmak üzere toplamda $10 \mathrm{sn}$ boya püskürtülmüştür. $85-115 \mathrm{~cm}$ uzaklıktaki bölgeye 4 adet numune koyularak beneklendirme işlemi yapılmıştır (Şekil 3.2). Beneklendirilmiş numuneler, Şekil 3.1'de sunulan sistematik deney programı dikkate alınarak kodlanmış ve her bir numune için VIC-2D yazılımının önerdiği alt küme boyutu ile DIC analizlerine başlanmıştır. Numune isimlendirmelerinde kullanılan kısaltmalar ve numune isimlendirmeleri her bir numune için Tablo 3.2'te ayrı ayrı verilmiştir. Kontrollü aydınlatmada LED ışıklar ve halojen ışık kaynağı 
kullanılmıştır. Kontrollü aydınlatmanın olmadığı durumda ise sadece oda içerisinde bulunan floresan 1şığından yararlanılmıştır. Yüksek çözünürlük için 2710x3384 piksel ve düşük çözünürlük için 1354x1692 piksel olacak şekilde görüntüler elde edilmiştir.
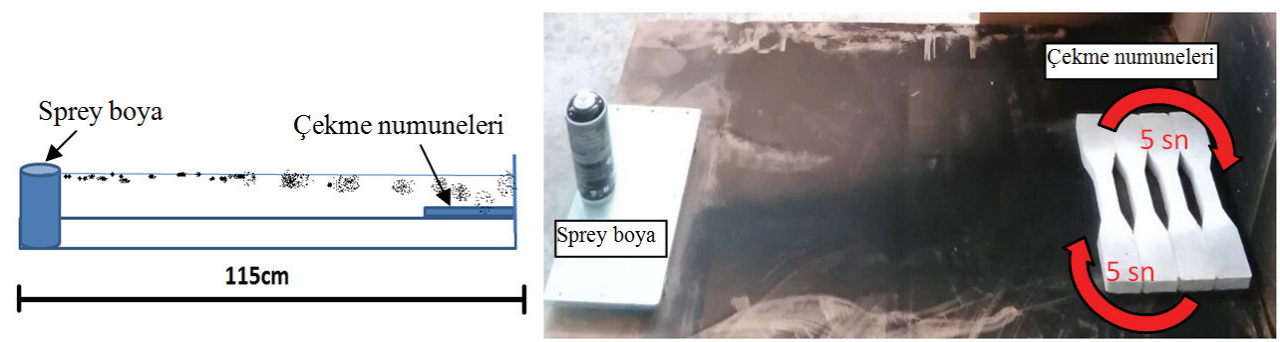

Şekil 3.2 - Sprey boya ile benekleme metodu

Tablo 3.2 - Hazırlanan numunelerin isimlendirme sistemi ve açıklamaları

\begin{tabular}{|c|c|}
\hline $\begin{array}{c}\text { Numune } \\
\text { Kodlama }\end{array}$ & Numune İsimleri \\
\hline AVYÇ & Kontrollü Aydınlatma var-Yüksek Çözünürlük \\
\hline AVDÇ & Kontrollü Aydınlatma var-Düşük Çözünürlük \\
\hline AYYÇ & Kontrollü Aydınlatma yok-Yüksek Çözünürlük \\
\hline AYDÇ & Kontrollü Aydınlatma yok-Düşük Çözünürlük \\
\hline
\end{tabular}
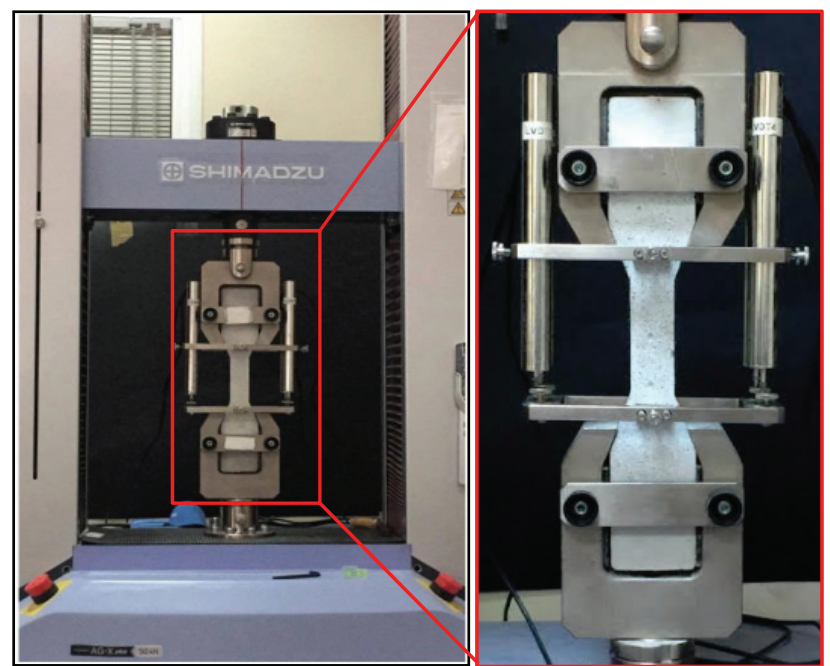

Şekil 3.3 - Doğrudan çekme cihazı ile düzeneğe yerleştirilmiş numune ve LVDT'ler 
Çekme deneylerinde $50 \mathrm{kN}$ kapasiteli SHIMADZU çekme cihazı kullanılmış ve yükleme hızı $0.5 \mathrm{~mm} / \mathrm{dk}$ olarak uygulanmıştır. Çekme cihazında 2 adet çene bulunmaktadır ve alt çene sabit olup üst çene ise tek mafsallıdır. İki tanesi numunenin ön yüzünde iki tanesi ise arka yüzünde olmak üzere dört adet LVDT, bir çerçeve yardımıyla numune etrafına yerleştirilmiştir (Şekil 3.3).

DIC analizleri için hazırlanan çekme deneyine bağlı kamera deney düzeneği Şekil 3.4'te sunulmuştur. Kameranın optik aksları numune üzerinde, numuneye dik ve aynı zamanda kamera ile numune yüzeyi birbirine paralel olacak şekilde konumlandırılmıştır. Bunun için üç eksenli su terazisinden ve lazer hizalayıcıdan faydalanılmıştır. Numune yüzeyini aydınlatmak için soğuk 1şık kaynağı kullanılmıştır.

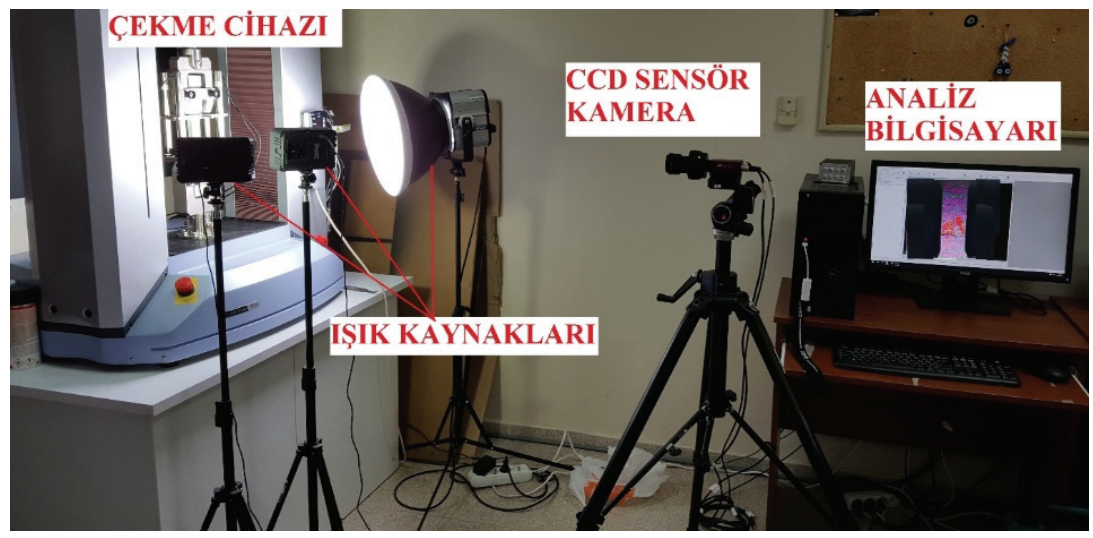

Şekil 3.4 - Çekme deneyinde kullanılan DIC deney düzeneği

Çekme deneyi süresince CCD sensörlü bir monokrom kamera ile her 5 saniyede bir görüntü kaydedilmiştir. Kullanılan kameranın donanımsal özellikleri Tablo 3.3'te verilmiştir.

Tablo 3.3 - Kamera özellikleri

\begin{tabular}{|l|l|}
\hline Çözünürlük & $3384 \times 2710$ piksel \\
\hline Sensör & 1 " CCD \\
\hline Lens & Rodegon 80, C-mount \\
\hline Maksimum kare/sn değeri & 10.1 kare/sn \\
\hline Bit derinliği & 8 -bit \\
\hline Çalışma Sıcaklığı & $(+5)^{\circ} \mathrm{C}$ ile $(+45)^{\circ} \mathrm{C}$ arasında \\
\hline Kamera türü & Monokrom \\
\hline Alan Derinliği & $4.8 \mathrm{~mm}$ \\
\hline Odak uzaklığı & $82.29 \mathrm{~mm}$ \\
\hline Uzatma tüpü & $48 \mathrm{~mm}$ \\
\hline
\end{tabular}




\subsection{DIC Analiz Parametrelerinin Seçilmesi}

VIC-2D yazılımı ile DIC parametrelerinin belirlenmesinde öncelikle analiz yapılacak bölge seçilmiş ve analizin başlaması için referans noktaları belirlenmiştir. Analizde yazılımın seçili bölge için tavsiye ettiği alt küme boyutu dikkate alınarak seçim yapılmıştır.

VIC-2D yazılımına bağlı analiz parametreleri, tüm numunelerin analizlerinde aynı olacak şekilde uygulanmıştır. Bunlar; eşleşen alt kümedeki piksellerin ağırlıklandırma şekli için Gauss ağırlık özelliği, alt piksel doğruluğu için gri alanları sürekli bir eğri ile temsil eden 8.dereceden bir eğri enterpolasyonudur. Her bir görüntüyü bir önceki görüntü ile ilişkilendiren artımlı korelasyon özelliği (incremental correlation) ve daha ayrıntılı arama (exhaustive search) özelliği kullanılmıştır. Analizlerde alt küme boyutu olarak, her bir numunenin ilk görüntüsü programda analiz edilerek programın önerdiği alt küme boyutları belirlenmiştir. Programın önerdiği alt küme boyutları beneklendirme, 1şıklandırma ve çözünürlük değişkenlerine bağlı olarak 17x17-37x37 piksel arasında değişmiştir. Anlamlı bir kıyaslamanın yapılabilmesi amacıyla programın önerdiği alt küme boyutu ile bu alt kümenin 0.5 ve 2 katı olmak üzere 3 farklı alt küme boyutu makale kapsamında incelenmek için seçilmiştir. Analiz adım aralığı değeri küçüldükçe alt küme eşleştirmeleri daha sık yapılacağından daha fazla korelasyon analizi gerçekleşecektir. Bu durumun deformasyon ölçümlerine doğrudan etki edeceği düşünülmektedir. Bu kapsamda, başlangıç adım aralığ1 literatürden elde edilen öneriler doğrultusunda alt küme boyutunun yarısı olarak seçilmiş ve 0,125 aralıklarla küçültülerek 3 farklı analiz adım aralığı daha belirlenmiştir [16,19,22]. Korelasyon yönteminin (SSD-NSSD) etkisini incelemek amacıyla sabit alt küme için 4 farklı analiz adım aralığı kullanılmıştır (Şekil 3.5). Analiz tamamlandıktan sonra şekil değişimi haritaları ve alansal birim şekil değişimi değerleri $\left(\varepsilon_{\mathrm{yy}}\right)$ (Formül 1) elde edilmiş ve grafikler oluşturulmuştur. DIC'de kullanılan $\varepsilon_{\mathrm{yy}}$ değerlerinin görüntü üzerindeki her bir piksel sütunundan elde edilişi Şekil 3.6'da gösterilmiştir.

Alt küme taraması için izlenen sistematik örneği

0.5 X Önerilen Önerilen 2 X Önerilen

\begin{tabular}{|c|c|c|c|}
\hline Alt küme & 15 & 31 & 61 \\
\hline $\begin{array}{l}\text { Adım aralığ } \\
(0.50 \text { X Ö.A })\end{array}$ & 8 & 15 & 30 \\
\hline
\end{tabular}

Korelasyon taraması için izlenen sistematik örneği

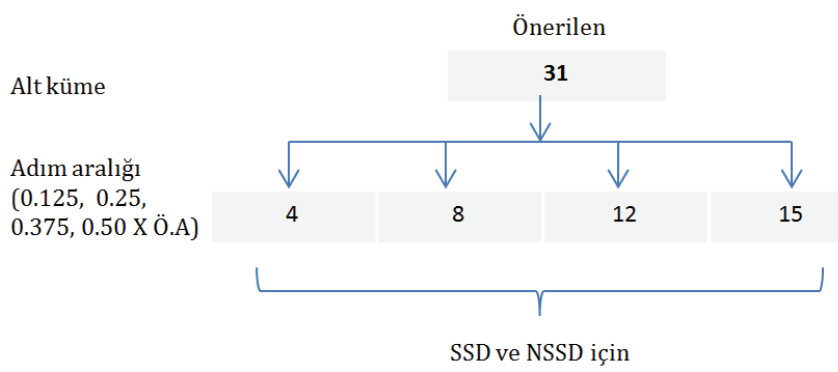

Şekil 3.5 - Analiz taraması için kullanılan sistematik 


$$
\varepsilon_{y y}=\frac{\partial u_{y}}{\partial y}+\frac{1}{2}\left[\left(\frac{\partial u_{x}}{\partial y}\right)^{2}+\left(\frac{\partial u_{y}}{\partial y}\right)^{2}\right]
$$

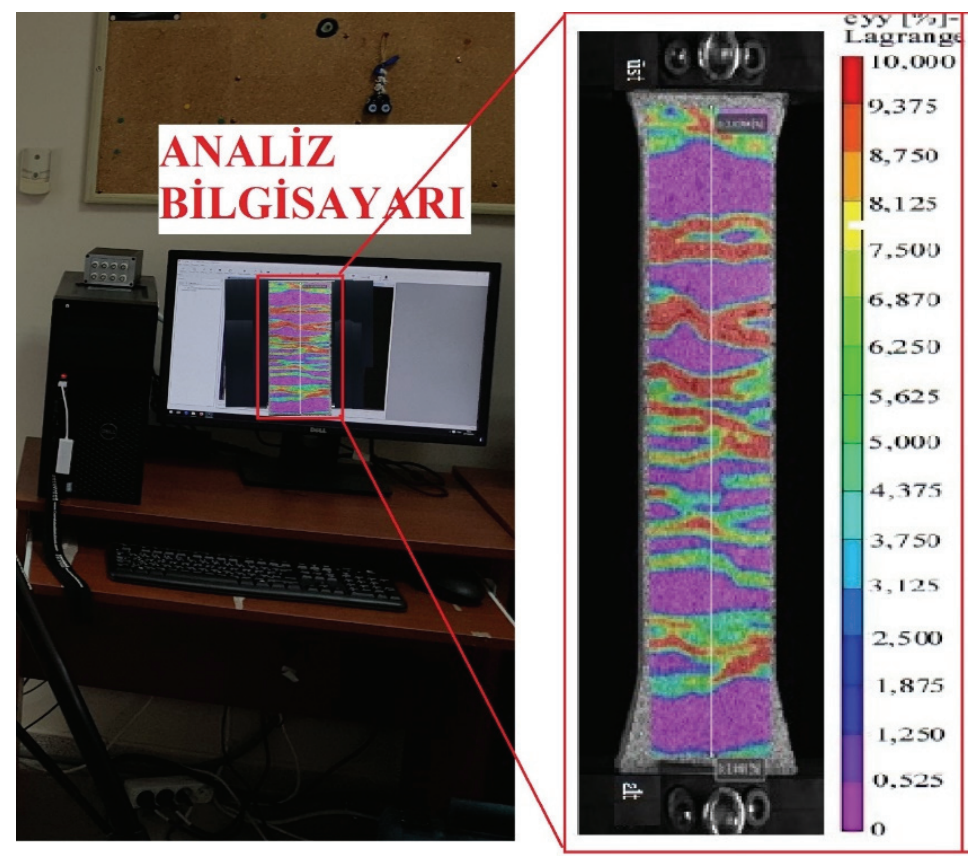

Şekil 3.6 - DIC'de kullanılan $\varepsilon_{y y}$ değerlerinin görüntü üzerinden elde edilişi

\subsection{LVDT ve DIC Sonuçlarının Kıyaslanmasında Kullanılan Yöntemler}

LVDT ve DIC analiz yöntemleri kullanılarak her bir numune için elde edilen $\varepsilon_{\text {LVDT }}$ ve $\varepsilon_{\text {DIC }}$ verileri ile sırasıyla $\sigma-\varepsilon_{\text {LVDT }}$ ve $\sigma-\varepsilon_{\text {DIC }}$ eğrileri çizdirilmiştir. AVYÇ1 numunesi için karşılaştırmalı LVDT ve DIC grafiği Şekil 3.7'da sunulmuştur. Alt küme boyutu 31x31 ve adım aralığı 15 olan NSSD korelasyon verilerinden $\% 0.5$ aralıklarla elde edilen $\varepsilon_{\text {DIC şekil }}$ değişimi haritalarının lokal şekil değiştirmeleri \%0-5 arasında ölçeklendirilmiştir.

LVDT değerleri referans alınarak aşağıdaki iki yöntem yardımıyla DIC verilerinin birim şekil değişimi analizlerinde kullanılabilirliği araştırılmıştır. Bu yöntemler;

1.yöntem; maksimum gerilme noktasına göre birim şekil değiştirmelerin kıyaslanmasıdır. $\sigma$ $\mathcal{E}$ diyagramında maksimum gerilmeye $\left(\sigma_{\text {mak }}\right)$ karşılık gelen birim şekil değiştirmelerin $\left(\varepsilon_{\text {LVDT }}\right.$ ve $\varepsilon_{\text {DIC }}$ ) kıyaslanmasıdır (Şekil 3.8). Bu yöntemde $\varepsilon_{\text {LVDT }}$ değerleri mutlak doğru kabul edilmiş ve $\varepsilon_{\text {DIC }}$ değerleri, $\varepsilon_{\text {LVDT }}$ değerlerinin yüzdesi olarak ifade edilmiştir $\left(\left(\varepsilon_{\mathrm{DIC}} / \varepsilon_{\mathrm{LVDT}}\right) \mathrm{x} 100\right)$. Bu metoda göre aşağıda gösterilen üç farklı durum ortaya çıkmaktadır:

$$
\left(\varepsilon_{\mathrm{DIC}} / \varepsilon_{\mathrm{LVDT}}\right) \mathrm{x} 100=100 \rightarrow \varepsilon_{\mathrm{DIC}}=\varepsilon_{\mathrm{LVDT}} \text { (Mükemmel ölçüm) }
$$

$\left(\varepsilon_{\text {DIC }} / \varepsilon_{\text {LVDT }}\right) \times 100>100 \rightarrow \varepsilon_{\text {DIC }}>\varepsilon_{\text {LVDT }}$ (DIC analiz verilerinin daha büyük olduğu)

$\left(\varepsilon_{\text {DIC }} / \varepsilon_{\text {LVDT }}\right) \times 100<100 \rightarrow \varepsilon_{\text {DIC }}<\varepsilon_{\text {LVDT }}$ (DIC analiz verilerinin daha küçük olduğu) 


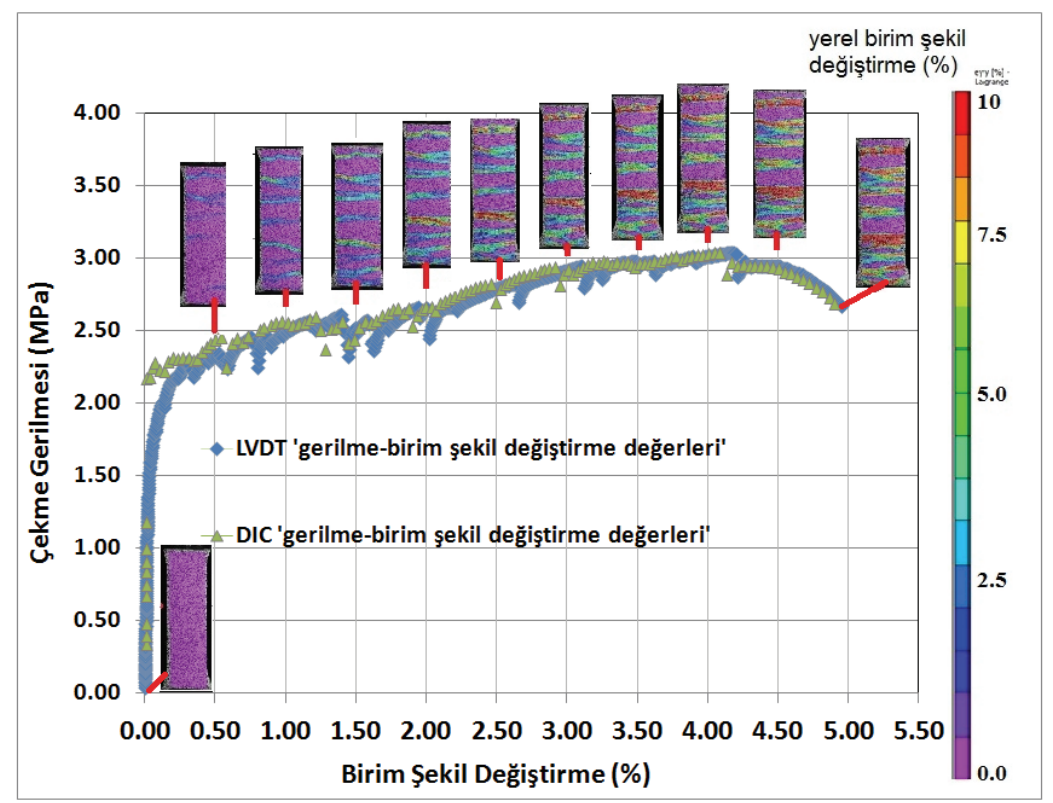

Şekil 3.7 - AVYÇ1 numunesinin LVDT ve DIC-NSSD korelasyonundaki veriler ile elde edilmiş gerilme-birim şekil değiştirme grafiği ve \% 0.5 aralıklı görüntüsü alınmış birim şekil değişimi haritaları

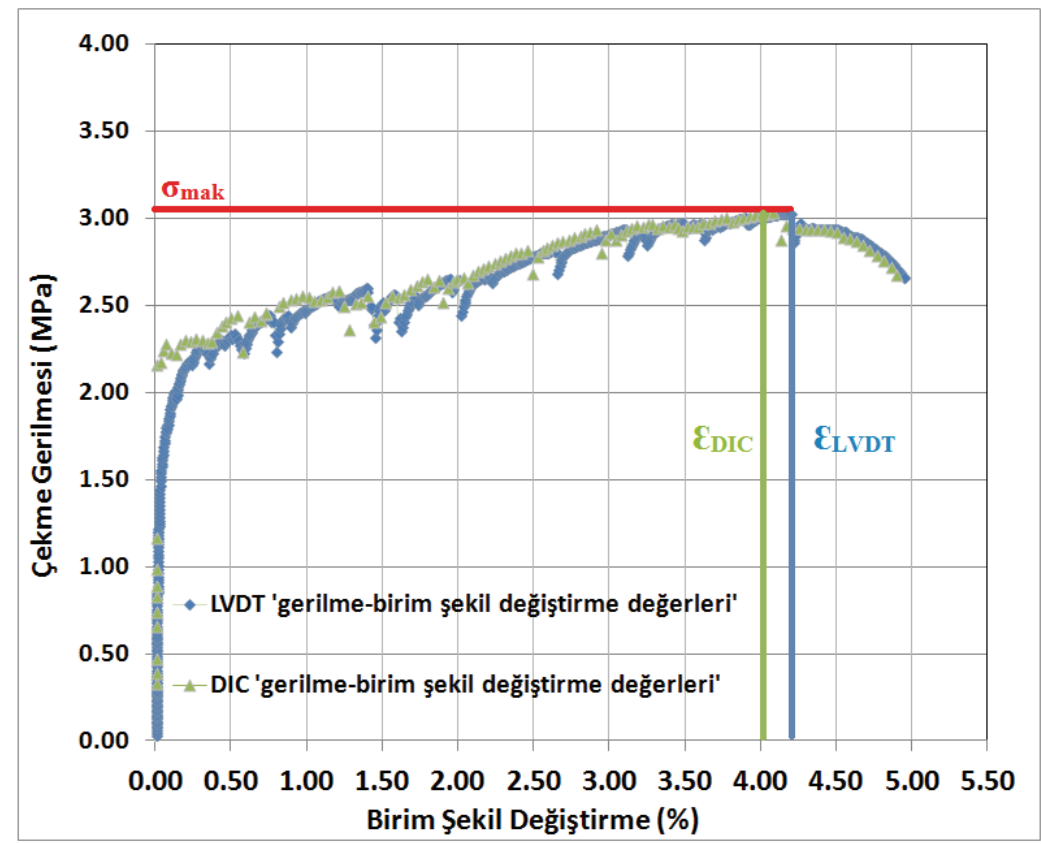

Şekil 3.8 - AVYÇ1 numunesi $\sigma-\mathcal{E}$ diyagramında maksimum gerilmeye $\left(\sigma_{\text {mak }}\right)$ karşılık gelen birim şekil değiştirmeler $\left(\varepsilon_{L V D T}\right.$ ve $\left.\varepsilon_{D I C}\right)$ 
2.yöntemde maksimum gerilme noktasına kadar tüm birim şekil değiştirme değerleri kıyaslanmıştır. $\sigma-\mathcal{E}$ diyagramında maksimum gerilmeye kadar her bir gerilme değerindeki LVDT ve DIC'nin birim şekil değiştirme değerlerini kıyaslama metodudur. Bu yöntemde eksenel sistemde düşey eksende $\varepsilon_{\text {DIC }}$ ve yatay eksende de karşılık gelen $\varepsilon_{\text {LVDT }}$ verilerinden oluşan eğriler çizdirilmiştir. Bu eğrilerin doğrusal denklemi elde edilmiş (Formül 2) ve doğru eğimleri (b) dikkate alınarak aşağıdaki yorumlar gerçekleştirilmiştir (Şekil 3.9). Doğru denklemlerine göre;

$\mathrm{y}=\mathrm{a}+\mathrm{b} . \mathrm{x} \rightarrow \varepsilon_{\text {DIC }}=\mathrm{a}+\mathrm{b} \cdot \varepsilon_{\mathrm{LVDT}}$

$$
\begin{gathered}
\mathrm{b}=1 \rightarrow \varepsilon_{\mathrm{DIC}}=\varepsilon_{\mathrm{LVDT}}(\text { Mükemmel ölçüm) } \\
\mathrm{b}>1 \rightarrow \varepsilon_{\mathrm{DIC}}>\varepsilon_{\mathrm{LVDT}}(\text { DIC analiz verilerinin daha büyük olduğu) } \\
\mathrm{b}<1 \rightarrow \varepsilon_{\mathrm{DIC}}<\varepsilon_{\mathrm{LVDT}}(\text { DIC analiz verilerinin daha küçük olduğu) }
\end{gathered}
$$

Burada, b değeri 1'e ne kadar yakın olursa, $\varepsilon_{\text {DIC }}$ ile $\varepsilon_{\text {LVDT }}$ verileri birbiriyle o kadar örtüşecektir. Eğer, b değerleri 1 den fazla olursa DIC analizinde LVDT ölçümlerine kıyasla daha yüksek şekil değişimi değerleri elde edilecektir. b değerinin 1'den az olması durumunda ise DIC analizi ile elde edilen şekil değişimi değerleri LVDT'ye kıyasla daha düşük olacaktır.

Geleneksel lifli kompozitlerin aksine, ECC'nin çoklu çatlama davranışı ve mekanik performansının değerlendirilmesinde $\sigma_{\text {mak }}$ 'dan önceki şekil değiştirme sertleşmesi davranışı bölgesi daha önemlidir. Bu nedenle, her iki yöntemde de $\sigma-\mathcal{E}$ diyagramında $\sigma_{\text {mak }}$ 'dan sonra karasız durumdaki göçme çatlağının hızlı bir şekilde belirginleşerek kompozitin yük taşıma kapasitesini yitirmeye ve kompozitin şekil değiştirme yumuşaması davranışı göstermeye başladığı göz önünde bulundurularak $\sigma_{\text {mak }}$ 'dan sonraki kısımlar hata hesaplamalarında dikkate alınmamıştır

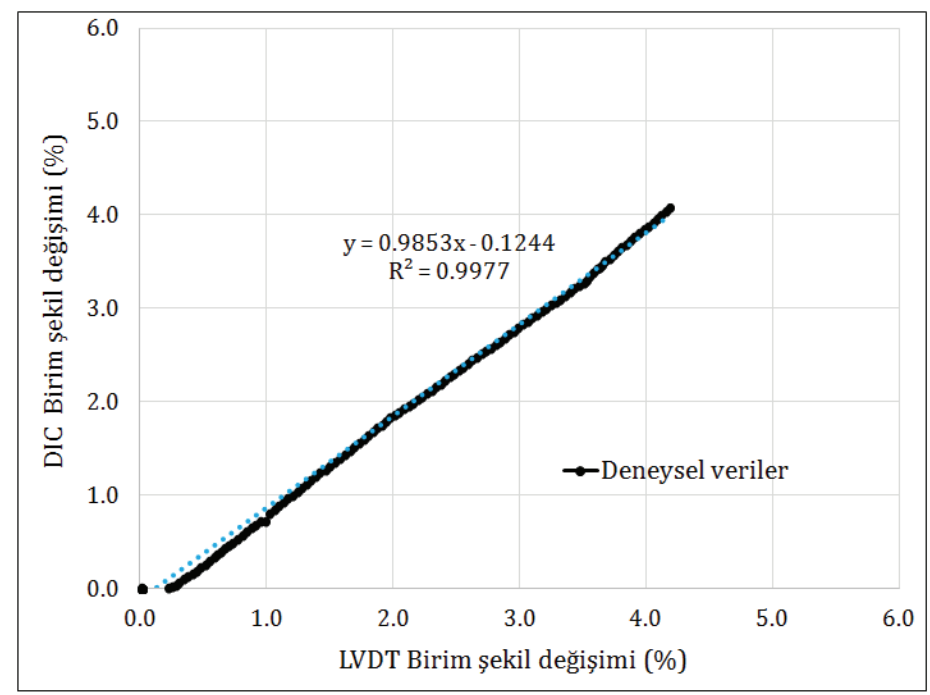

Şekil 3.9 - AVYÇ1 numunesi LVDT ve DIC’nin tüm birim şekil değiştirme verilerinin klyaslanmasl 


\section{BULGULAR VE TARTIŞMA}

\subsection{Yöntemlere Göre Hata Oranlarının Değerlendirilmesi}

Önerilen alt kümenin kendisi, yarısı ve iki katı olan alt kümeler kullanılarak ve adım aralığı olarak da alt kümelerin yarısı seçilerek yapılan analizlerin sonuçları Tablo 4.1 ve 4.2'de verilmiştir. Önerilen alt kümenin iki katındaki alt küme için yapılan analizlerde hata yüzdesinin genellikle daha az olduğu gözlenmiştir. Önerilen alt kümenin iki katı için yapılan analizlerde hata yüzdeleri minimum \%2.2 maksimum ise \%10.9'dur. Genel olarak önerilen alt kümeden daha yüksek alt kümelerde çalışmak hata yüzdesini düşürürken (\%3-7) önerilen alt kümeden daha düşük alt kümelerde çalışmak hata yüzdesini çok yüksek mertebelere çekmektedir (\%7-75). Her bir alt küme durumu için hata oranları en az olan analiz koşulları koyu renk ile vurgulanmıştır. Tablo 4.1 ve 4.2 'de elde edilen sonuçların ortalamaları dikkate alınarak: Tablo 4.1'in daha rahat ve anlaşılabilir bir şekilde incelenmesi amacıyla Tablo 4.3 ve 4.4; , Tablo 4.2'nin daha rahat ve anlaşılabilir bir şekilde incelenmesi amacıyla Tablo 4.5 ve 4.6 oluşturulmuştur.

Tablo 4.1 - 1.yöntem: Maksimum gerilme noktasina göre LVDT ve DIC birim şekil değiştirmeleri kıyaslama sonuçları (3 farklı alt küme)

\begin{tabular}{|c|c|c|c|c|c|c|}
\hline \multirow{2}{*}{ No } & \multirow{2}{*}{$\begin{array}{c}\text { Numune } \\
\text { Kodu }\end{array}$} & Numune İsimleri & \multicolumn{3}{|c|}{ (EDIC / } & \multicolumn{2}{|c|}{ LVDT)x100 } \\
\cline { 4 - 7 } & AVYÇ & $\begin{array}{c}\text { Kontrollü aydı̈nlatma (AV), } \\
\text { Yüksek çözünürlük (YÇ) }\end{array}$ & $\mathbf{9 2 . 8}$ & $\mathbf{9 5 . 9}$ & $\mathbf{9 7 . 1}$ & $\mathbf{9 5 . 3}$ \\
\hline 2 & AVDÇ & $\begin{array}{c}\text { Kontrollü aydı̈nlatma (AV), } \\
\text { Düşük çözünürlük (DÇ) }\end{array}$ & 146.3 & 115.0 & 110.9 & 124.1 \\
\hline 3 & AYYÇ & $\begin{array}{c}\text { Kontrolsüz aydınlatma (AY), } \\
\text { Yüksek çözünürlük (YÇ) }\end{array}$ & $\mathbf{1 0 6 . 2}$ & 109.1 & 105.4 & 106.9 \\
\hline 4 & AYDÇ & $\begin{array}{c}\text { Kontrolsüz aydı̈nlatma (AY), } \\
\text { Düşük çözünürlük (DÇ) }\end{array}$ & 138.9 & 112.1 & 106.9 & 119.3 \\
\hline
\end{tabular}

*Ö.A:Programa tarafindan önerilen alt küme

**Her bir değer 12 sayısal değerin (4 Numune, 3 farklı alt küme ve her alt küme için 1 adım aralığı) ortalamasını ifade etmektedir.

Tablo 4.2 - 2.yöntem: Tüm Birim Şekil Değiştirme Değerlerine göre LVDT ve DIC klyaslama sonuçları (3 farklı alt küme)

\begin{tabular}{|l|c|c|c|c|c|c|}
\hline \multirow{2}{*}{ No } & \multirow{2}{*}{$\begin{array}{c}\text { Numune } \\
\text { Kodu }\end{array}$} & Numune İsimleri & \multicolumn{4}{|c|}{ b*100 $^{*}$} \\
\cline { 4 - 7 } & AVYÇ & $\begin{array}{c}\text { Kontrollü aydı̈nlatma (AV), } \\
\text { Yüksek çözünürlük (YÇ) }\end{array}$ & $\mathbf{9 3 . 7}$ & $\mathbf{9 7 . 3}$ & $\mathbf{9 7 . 5}$ & $\mathbf{9 6 . 2}$ \\
\hline 1 & AVDÇ.A & $\begin{array}{c}\text { Kontrollü aydı̈nlatma (AV), } \\
\text { Düşük çözünürlük (DÇ) }\end{array}$ & 141.1 & 110.5 & 110.7 & 120.8 \\
\hline
\end{tabular}


Tablo 4.2 - 2.yöntem: Tüm Birim Şekil Değiştirme Değerlerine göre LVDT ve DIC klyaslama sonuçları (3 farklı alt küme) (devam)

\begin{tabular}{|l|c|c|c|c|c|c|}
\hline No & $\begin{array}{c}\text { Numune } \\
\text { Kodu }\end{array}$ & Numune İsimleri & \multicolumn{4}{|c|}{ b*100 } \\
\hline 3 & AYYÇ & $\begin{array}{c}\text { Kontrolsüz aydinlatma (AY), } \\
\text { Yüksek çözünürlük (YÇ) }\end{array}$ & 114.4 & 105.9 & $\mathbf{1 0 2 . 2}$ & 107.5 \\
\hline 4 & AYDÇ & $\begin{array}{c}\text { Kontrolsüz aydinlatma (AY), } \\
\text { Düşük çözünürlük (DÇ) }\end{array}$ & 175.9 & 111.2 & 106.2 & 131.1 \\
\hline
\end{tabular}

*Ö.A: Programa tarafindan önerilen alt küme

**Her bir değer 12 sayısal değerin (4 Numune, 3 farklı alt küme ve her alt küme için 1 adım aralığı) ortalamasını ifade etmektedir.

Kontrollü aydınlatma etkisi dikkate alınarak oluşturulan Tablo 4.3 incelendiğinde, yüksek çözünürlük durumunda kontrollü aydınlatma ve düşük çözünürlük durumunda ise kontrolsüz aydınlatmanın daha az hata oranları verdiği belirlenmiştir.

Tablo 4.3 - Kontrollü Aydınlatma Etkisi (1. Yöntemin dĕgerlendirilmesi)

\begin{tabular}{|l|l|l|l|}
\hline $\begin{array}{l}\text { İncelerken Sabit Tutulan } \\
\text { Parametreler }\end{array}$ & $\begin{array}{l}\text { Tablo 4.1'de } \\
\text { Kiyaslanan satırlar }\end{array}$ & $\begin{array}{l}\text { Kontrollü } \\
\text { aydınlatma }\end{array}$ & $\begin{array}{l}\text { Kontrolsüz } \\
\text { aydınlatma }\end{array}$ \\
\hline Yüksek çözünürlük (YÇ) & $1-3$ & + & \\
\hline Düşük çözünürlük (DÇ) & $2-4$ & & + \\
\hline
\end{tabular}

*+ işareti hatanın daha az olduğu aydınlatma etkisi göstermektedir.

** Kıyaslamalar ortalama hatalara göre yapılmıştır.

Yapılan analizler sonucunda oluşturulan Tablo 4.4 değerlendirildiğinde tamamında yüksek çözünürlükte hata oranının daha az olduğu sonucuna varılmıştır.

Tablo 4.4. Çözünürlük Etkisi (1. Yöntemin değerlendirilmesi)

\begin{tabular}{|l|l|l|l|}
\hline $\begin{array}{l}\text { Incelerken Sabit Tutulan } \\
\text { Parametreler }\end{array}$ & $\begin{array}{l}\text { Tablo 4.1'de } \\
\text { Kiyaslanan satırlar }\end{array}$ & $\begin{array}{l}\text { Yüksek } \\
\text { çözünürlük }\end{array}$ & $\begin{array}{l}\text { Düşük } \\
\text { çözünürlük }\end{array}$ \\
\hline Kontrollü aydınlatma (AV) & $1-2$ & + & \\
\hline Kontrolsüz aydınlatma (AY) & $3-4$ & + & \\
\hline
\end{tabular}

*+ işareti hatanın daha az olduğu aydınlatma etkisi göstermektedir.

** Kıyaslamalar ortalama hatalara göre yapılmıştır.

Kontrollü aydınlatma etkisinin değerlendirilmesi için oluşturulan Tablo 4.5 incelendiğinde kontrollü aydınlatmanın daha az hata verdiği görülmüştür. 
Tablo 4.5 - Kontrollü Aydınlatma Etkisi (2. Yöntemin değerlendirilmesi)

\begin{tabular}{|l|l|l|l|}
\hline $\begin{array}{l}\text { İncelerken Sabit Tutulan } \\
\text { Parametreler }\end{array}$ & $\begin{array}{l}\text { Tablo 4.2'de } \\
\text { Kiyaslanan satırlar }\end{array}$ & $\begin{array}{l}\text { Kontrollü } \\
\text { aydınlatma }\end{array}$ & $\begin{array}{l}\text { Kontrolsüz } \\
\text { aydınlatma }\end{array}$ \\
\hline Yüksek çözünürlük (YÇ) & $1-3$ & + & \\
\hline Düşük çözünürlük (DÇ) & $2-4$ & + & \\
\hline
\end{tabular}

*+ işareti hatanın daha az olduğu aydınlatma etkisi göstermektedir.

** Kıyaslamalar ortalama hatalara göre yapılmıştır.

Tablo 4.6'ya göre aydınlatmanın kontrollü veya kontrolsüz olması durumlarının tamamında yüksek çözünürlükte hata oranının daha az olduğu sonucuna varılmıştır.

Tablo 4.6 - Çözünürlük Etkisi (2. Yöntemin değerlendirilmesi)

\begin{tabular}{|l|l|l|l|}
\hline $\begin{array}{l}\text { Incelerken Sabit Tutulan } \\
\text { Parametreler }\end{array}$ & $\begin{array}{l}\text { Tablo 4.2'de } \\
\text { Kiyaslanan satırlar }\end{array}$ & $\begin{array}{l}\text { Yüksek } \\
\text { çözünürlük }\end{array}$ & $\begin{array}{l}\text { Düşük } \\
\text { çözünürlük }\end{array}$ \\
\hline Kontrollü aydınlatma (AV) & $1-2$ & + & \\
\hline Kontrolsüz aydınlatma (AY) & $3-4$ & + & \\
\hline
\end{tabular}

*+ işareti hatanın daha az olduğu aydınlatma etkisi göstermektedir.

** Kıyaslamalar ortalama hatalara göre yapılmıştır.

Tablo 4.7 ve Tablo 4.8'de korelasyon yönteminin etkisini görmek için NSSD ve SSD korelasyonları kullanılarak yapılan analiz sonuçlarının verileri verilmiştir.

Tablo 4.7 ve 4.8 'e göre analizlerde NSSD veya SSD yöntemlerini kullanmak önemsenecek bir farka neden olmamaktadır.

Tablo 4.7 - Maksimum gerilme noktasına göre LVDT ve DIC birim şekil değiştirmeleri kıyaslama sonuçları (SSD)

\begin{tabular}{|c|l|l|l|}
\hline $\begin{array}{l}\text { Satır } \\
\text { No }\end{array}$ & $\begin{array}{l}\text { Numune } \\
\text { Kodu }\end{array}$ & Numune İsimleri & $\begin{array}{l}\left(\mathcal{E}_{\text {DIC }}\right. \\
\left./ \mathcal{E}_{\text {LVDT }}\right) \mathrm{x} 100\end{array}$ \\
\hline 1 & AVYÇ & Kontrollü aydınlatma (AV), Yüksek çözünürlük (YÇ) & 101.4 \\
\hline 2 & AVDÇ & Kontrollü aydınlatma (AV), Düşük çözünürlük (DÇ) & 117.1 \\
\hline 3 & AYYÇ & Kontrolsüz aydınlatma (AY), Yüksek çözünürlük (YÇ) & 112.4 \\
\hline 4 & AYDÇ & Kontrolsüz aydınlatma (AY), Düşük çözünürlük (DÇ) & 114.1 \\
\hline
\end{tabular}

*Her bir değer 16 sayısal değerin (4 Numune, 1 alt küme ve her alt küme için 4 farklı adım aralığı) ortalamasını ifade etmektedir. 
Tablo 4.8 - Maksimum gerilme noktasına göre LVDT ve DIC birim şekil değiştirmeleri kıyaslama sonuçları(NSSD)

\begin{tabular}{|c|l|l|l|}
\hline $\begin{array}{l}\text { Satır } \\
\text { No }\end{array}$ & $\begin{array}{l}\text { Numune } \\
\text { Kodu }\end{array}$ & Numune İsimleri & $\begin{array}{l}\left(\varepsilon_{\text {DIC }}\right. \\
\left./ \varepsilon_{\text {LVDT }}\right) \times 100\end{array}$ \\
\hline 1 & AVYÇ & Kontrollü aydınlatma (AV), Yüksek çözünürlük (YÇ) & 101.3 \\
\hline 2 & AVDÇ & Kontrollü aydınlatma (AV), Düşük çözünürlük (DÇ) & 117.1 \\
\hline 3 & AYYÇ & Kontrolsüz aydınlatma (AY), Yüksek çözünürlük (YÇ) & 112.4 \\
\hline 4 & AYDÇ & Kontrolsüz aydınlatma (AY), Düşük çözünürlük (DÇ) & 114.1 \\
\hline
\end{tabular}

*Her bir değer 16 sayısal değerin (4 Numune, 1 alt küme ve her alt küme için 4 farklı adım aralığı) ortalamasını ifade etmektedir.

\subsection{Kontrollü Aydınlatmanın Hata Oranlarına Etkisini Değerlendirmek İçin Yapılan Analizler}

Üretilen numunelerden temsili 4 tanesi (iki tanesi kontrollü aydınlatma yapılan; diğer ikisi kontrollü aydınlatma yapılmayan) üzerinde bir dizi ilave incelemeler gerçekleştirilmiştir. Analiz edilecek bölgelerin gri renk skalalarına ait histogramlar yazılan bir MATLAB algoritması aracılığıyla elde edilmiştir (Şekil 4.1 ve Şekil 4.2). Ayrıca, benekleme yoğunluklarının hesaplanması amacıyla bu bölgelere ait ikili görüntüler oluşturulmuştur. İkili görüntüler elde edilirken, gri renk skalasının medyan değeri (127) referans alınarak bu değerden küçük ve büyük değerler sırasıyla 0 'a ve 255 'e ötelenmiştir. İkili görüntü sisteminde 0 değeri siyahı 255 değeri ise beyazı temsil etmektedir. Elde edilen ikili görüntüler kullanılarak, 0 değerine ötelenmiş piksel sayısının tüm piksel sayısına oranına hesaplanmış ve bu değer "benek yoğunluğu" olarak adlandırılmıştır.

Analiz sonuçlarına göre, kontrollü aydınlatma yapılması durumunda benek yoğunluğu \%20 mertebelerinde iken kontrollü aydınlatmanın yapılmadığı durumda benek yoğunluğu \%50 olarak belirlenmiştir. $\mathrm{Bu}$ durumun temel nedeni kontrolsüz aydınlatma durumunda oda lambasının yukarıda olması nedeniyle numune yüzeyinde meydana gelen gölgelerdir. Oluşan gölgelenmenin, analizde yazılım tarafından hata payını arttırıcı ek benekler gibi algılandığı MATLAB algoritması yardımıyla elde edilen ikili görüntüler yardımıyla ispatlanmıştır (Şekil 4.2).

Numunelerde kontrollü aydınlatma sağlandığında, yapay gölgelenmelerin olmadığı ve kontrastın daha belirgin olduğu elde edilen histogramlarda görülmektedir (Şekil 4.1). Kontrolsüz aydınlatma ortamında elde edilmiş görüntülerde ise numune üzerinde gölgelenmelerin oluşması gri ton değerlerinin daha fazla görüldüğü bir histograma neden olmuştur (Şekil 4.2). Bu durum hata oranlarını özellikle yüksek çözünürlükte 12-15 kata kadar arttırmıştır. Diğer taraftan düşük çözünürlükte alınan görüntülerle aydınlatma kontrolünün belirgin bir faydası olmamıştır. Çünkü düşük çözünürlükte alınan görüntülerde zaten analiz verisi kısıtlı olduğu için hata oranı baştan yüksektir. 

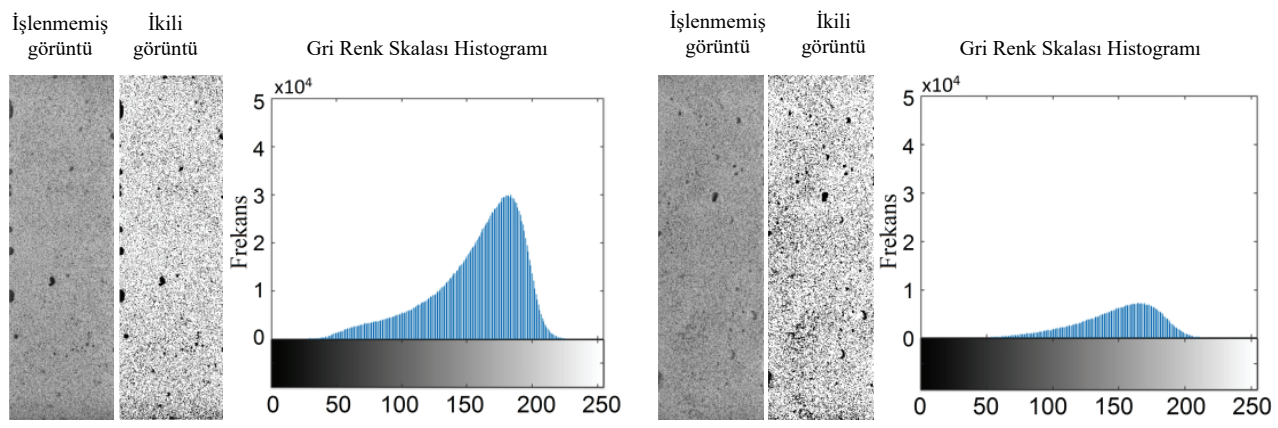

AVYÇ

AVDÇ

Şekil 4.1 - Kontrollü aydınlatma yapılan numunelerin gri renk skalası histogramları
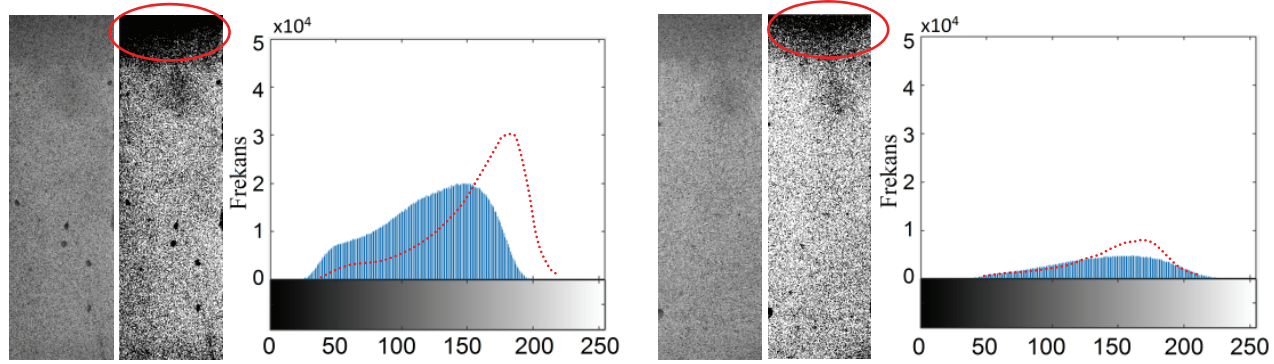

AYYÇ

AYDÇ

Şekil 4.2 - Kontrollü aydınlatma yapılmayan numunelerin gri renk skalası histogramları

\section{3. Çözünürlüğün Hata Oranlarına Etkisi Üzerine Değerlendirilmeler}

Şekil 4.1 ve Şekil 4.2'deki histogramlarda bekleneceği üzere düşük çözünürlüklü numunelerdeki elde edilen veri (piksel) sayısının yüksek çözünürlüğe oranla daha düşük olduğu belirgin olarak görülebilmektedir. Elde edilen veriler düşük çözünürlük için dörtte bir oranındadır. Bu oran Şekil 4.3'de kırmızı renkle işaretlenen bölgelerle ispatlanmıştır. Bu sonuçtan yola çıkılarak, elde edilen verilerin (DIC analizlerinde kullanılan veri noktalarının) yüksek çözünürlüklü görüntülerde düşük çözünürlüklü görüntülere kıyasla 4 kat daha fazla olduğu söylenebilir. Şekil değiştirme sınırlı bir bölgeden başlayan ve yayılım gösteren lokal bir olgudur. Lokal şekil değiş̧imi doğrudan hasar başlangıcı ve gelişimi ile ilgili olduğundan yüksek çözünürlüklü görüntü, şekil değiştirmeyi tespit etmek için bir ihtiyaçtır [23]. Görüntü çözünürlüğündeki artış ile analizlerdeki hata oranlarının azaltılması mümkündür [24]. Bu kapsamda, lokal şekil değişimindeki küçük gelişimlerin tespiti için yüksek çözünürlüklü ölçümler daha hassas sonuçlar verecektir. Deneysel çalışmalar kapsamında elde edilen hata oranları incelendiğinde de (Tablo 4.1 ve Tablo 4.2) düşük çözünürlüklü numune analizlerinde her zaman bu hata oranının daha fazla olduğu görülmektedir. 


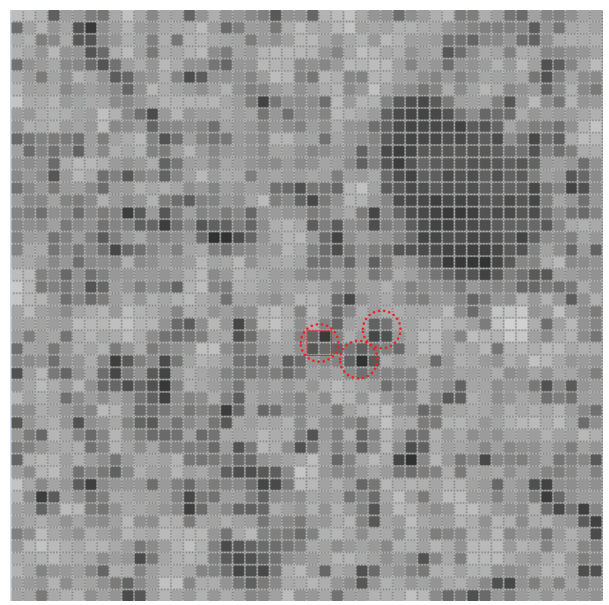

(a)

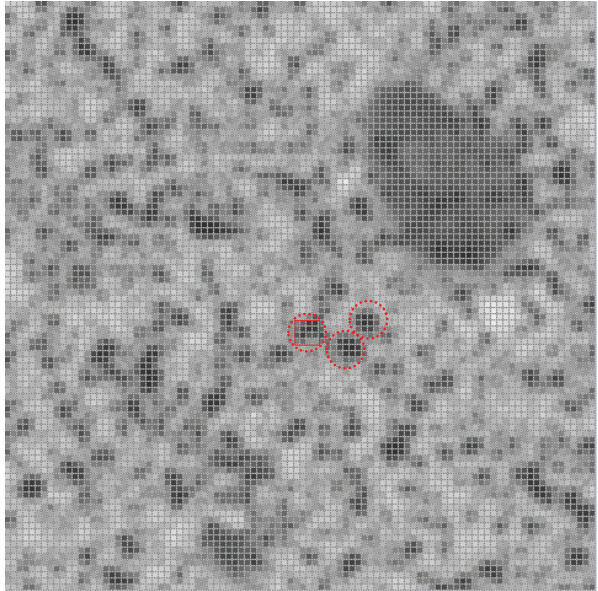

(b)

Şekil 4.3 - a)Düşük çözünürlük, b)Yüksek çözünürlük (örn: AVDÇ1 numunesi).

\section{SONUÇLAR VE ÖNERILER}

Deneysel çalışma kapsamında 16 adet ECC numunesi üzerinde toplam 2088 adet dijital görüntü işlenerek 112 DIC analizi gerçekleştirilmiştir. Bu analizler sonucunda 2 farklı hata kıyaslama yöntemi kullanılarak şu sonuçlara ulaşılmıştır:

- Önerilen alt küme boyutunun iki katı, yarısı ve kendisi için yapılan analizlerin ortalamaları 1. yönteme (maksimum gerilme noktasına göre kıyaslama) göre değerlendirildiğinde LVDT değerlerine en yakın sonucu \%4.7'lik hata ile AVYÇ (Kontrollü Aydınlatma-Yüksek Çözünürlük) numunesi vermiştir.

- Verilerin ortalamaları 2. yönteme (tüm birim şekil değiştirmelere göre kıyaslama) göre değerlendirildiğinde AVYÇ (Kontrollü Aydınlatma-Yüksek Çözünürlük) numunesi \%3.8 hata ile LVDT değerlerine yaklaşılmıştır.

- Alt küme bazında ise 1. yönteme göre AVYÇ (Kontrollü aydınlatma-Yüksek çözünürlük) numunesi alt küme olarak önerilen alt kümenin iki katı kullanılarak yapılan analizde \%2.9'luk hata ile en iyi sonucu vermiştir. Önerilen alt kümenin yarısını kullanmak \%6.2 ile \%46.3 oranları arasında değişen hatalara sebep olmuştur. Önerilen alt kümenin iki katını kullanmak ise maksimum \%10.9'luk hataya neden olmuştur. Bu kıyaslama sonucunda önerilen alt kümenin üzerine çıkmanın DIC değerlerini LVDT'ye büyük oranda yaklaştırdığı tespit edilmiştir. Alt küme boyutunun daha fazla arttırılmasının sonuçları ve analiz süresini ne derece değiştireceği ayrıca incelenmelidir.

- Alt küme bazında 2. yönteme göre kıyaslandığında AYYÇ (Kontrolsüz aydınlatmaYüksek çözünürlük) numunesi alt küme olarak önerilen alt kümenin iki katı kullanılarak yapılan analizde \%2.2'lik hata ile LVDT'ye en yakın sonucu vermiştir. 2. 
yönteme göre çoğu numunede en iyi sonucu önerilen alt kümenin iki katının kullanılması vermiştir.

- Çalışma kapsamında elde edilen görüntülerde, yüksek çözünürlüklü görüntülerin düşük çözünürlüklü görüntülere kıyasla 4 kat daha fazla veri içerdiği tespit edilmiştir. Bu durumun bir sonucu olarak, yüksek çözünürlüklü görüntülerle yapılan analizlerde hata oranlarının daha düşük olduğu belirlenmiştir.

- Korelasyon yönteminin etkisini görmek için NSSD ile SSD yöntemleri kıyaslanmıştır. Analizler sonucunda iki yöntemin birbiriyle \%99 oranında benzer sonuçlar verdiği tespit edilmiştir. Bu çalışmada incelenen kontrollü aydınlatma ve yüksek çözünürlük koşullarında her iki korelasyon yönteminin de kullanılabileceği sonucuna ulaşılmıştır.

- Kontrollü aydınlatma durumunda benek yoğunluğu \%20 mertebelerinde iken kontrollü aydınlatmanın yapılmadığı durumda benek yoğunluğu \%50 olarak hesaplanmıştır. Kontrolsüz aydınlatma durumunda meydana gelen yapay gölgelenmeler, kontrollü aydınlatma sağlandığında giderilmiş ve görüntü kontrastı daha belirgin hale gelmiştir. Yüksek çözünürlüklü görüntülerde kontrollü aydınlatma hata oranlarını önemli derecede azaltırken, düşük çözünürlüklü görüntülerde aydınlatma kontrolünün belirgin bir etkisi olmamıştır.

- Yüksek çözünürlük ve kontrollü aydınlatma ile elde edilmiş bir görüntüde uygun boyutta alt küme belirlendiği zaman DIC analiz sonuçları gerçek LVDT değerleri ile örtüşmektedir. DIC yönteminde, kontrollü aydınlatma ortamında yüksek çözünürlükle çekilen görüntülerden elde edilen birim şekil değiştirmeleri ile LVDT'lerden elde edilen birim şekil değiştirmelerinin farkı $\pm \%$ 2-8 arasında küçük mertebelerde olduğu görülmüştür. Böylece bu makale kapsamına dâhil olmayan, bir sonraki aşamada gerçekleştirilecek çoklu çatlak analizi için gerekli lokal birim şekil değişimlerin DIC yöntemiyle hassas bir şekilde elde edildiği tespit edilmiştir.

\section{Teşekkür}

Bu çalışma kapsamındaki deney ve analizler bir TÜBİTAK projesi (Proje No: 115R012) kapsamında gerçekleştirilmiştir. Sağladığı ekipman ve maddi desteklerinden dolayı TÜBİTAK'a teşekkürlerimizi sunarız.

\section{Kaynaklar}

[1] Dhawale, A. W., \& Joshi, V. P., Engineered cementitious composites for structural applications, International journal of application or Innovation in Engineering \& Management, 2, 198-205, 2013.

[2] Sherir, M. A., Hossain, K. M. A., \& Lachemi, M., MAT-731: Mechanical \& Durability Properties Of Engineered Cementitious Composites With Different Aggregates, 2016.

[3] Li, V. C., Can Concrete Be Bendable? The notoriously brittle building material may yet stretch instead of breaking, American Scientist, 100(6), 484-93, 2012. 
[4] Li, V. C, Miahra D.K., Wu H. C., Matrix Design for Pseudo Strain-Hardening Fiber Reinforced Cementitious Composites, Materials and structures, pp. 586, 1995.

[5] Ohno, M., \& Li, V. C., A feasibility study of strain hardening fiber reinforced fly ashbased geopolymer composites, Construction and Building Materials, 57, 163-168, 2014.

[6] Felekoglu, B., \& Keskinates, M., Multiple cracking analysis of HTPP-ECC by digital image correlation method, Computers and Concrete, 17(6), 831-848, 2016.

[7] Pérez, J. A., Coppieters, S., \& Debruyne, D., Influence of the Paint Coating Thickness in Digital Image Correlation Experiments, World Academy of Science, Engineering and Technology, International Journal of Computer, Electrical, Automation, Control and Information Engineering, 9(7), 1660-1664, 2015.

[8] Aydın, M., Wu, X., Çetinkaya, K., Kadı, İ., \& Yaşar, M., Application of Digital Image Correlation in Uniaxial Tensile Test, European Journal of Engineering and Natural Sciences, 1(1), 2015.

[9] Kashfuddoja, M., Prasath, R. G. R., \& Ramji, M., Study on experimental characterization of carbon fiber reinforced polymer panel using digital image correlation: A sensitivity analysis, Optics and Lasers in Engineering, 62, 17-30, 2014.

[10] Pan, B., Tian, L., \& Song, X., Real-time, non-contact and targetless measurement of vertical deflection of bridges using off-axis digital image correlation, NDT \& E International, 79, 73-80, 2016.

[11] Liu, X. Y., Li, R. L., Zhao, H. W., Cheng, T. H., Cui, G. J., Tan, Q. C., \& Meng, G. W., Quality assessment of speckle patterns for digital image correlation by Shannon entropy, Optik-International Journal for Light and Electron Optics, 126(23), 42064211, 2015.

[12] Liang, Z., Yin, B., Liu, H., Mo, J., \& Wang, S., Displacement measurement of specimen surfaces with dam aged areas by digital image correlation, Measurement, 76, 183-188, 2015.

[13] Chen, X., Yang, L., Xu, N., Xie, X., Sia, B., \& Xu, R., Cluster approach based multicamera digital image correlation: Methodology and its application in large area high temperature measurement, Optics \& Laser Technology, 57, 318-326, 2014.

[14] Haddadi, H., \& Belhabib, S., Use of rigid-body motion for the investigation and estimation of the measurement errors related to digital image correlation technique, Optics and Lasers in Engineering, 46(2), 185-196, 2008.

[15] Hedayat, A., \& Ashur, S., Digital image correlation and its application in an undergraduate Civil Engineering Materials Laboratory, 2015.

[16] Cooreman, S., Lecompte, D., Sol, H., Vantomme, J., \& Debruyne, D., Identification of mechanical material behavior through inverse modeling and DIC, Experimental Mechanics, 48(4), 421-433, 2008. 
[17] Khoo, S. W., Karuppanan, S., \& Tan, C. S., A Review of Surface Deformation and Strain Measurement Using Two-Dimensional Digital Image Correlation, Metrology and Measurement Systems, 23(3), 461-480, 2016.

[18] Bomarito, G. F., Hochhalter, J. D., \& Cannon, A. H., Image Correlation Pattern Optimization for Micro-Scale In-Situ Strain Measurements, 2016.

[19] Ke, X. D., Schreier, H. W., Sutton, M. A., \& Wang, Y. Q., Error assessment in stereobased deformation measurements, Experimental Mechanics, 51(4), 423-441, 2011.

[20] Sutton, M. A., Orteu, J. J., \& Schreier, H., Image correlation for shape, motion and deformation measurements: basic concepts, theory and applications, Springer Science \& Business Media, 2009.

[21] Japan Society of Civil Engineers (JSCE), Recommendations for design and construction of high performance fiber reinforced cement composites with multiple fine cracks (HPFRCC), Tokyo, Japan, 1-88, 2008.

[22] Reu, P., Stereo-Rig Design: Creating the Stereo-Rig Layout-Part 1, Experimental Techniques, 36(5), 3-4, 2012.

[23] Yang, Y., Sun, P., Nagarajaiah, S., Bachilo, S. M., \& Weisman, R. B., Full-field, highspatial-resolution detection of local structural damage from low-resolution random strain field measurements, Journal of Sound and Vibration, 399, 75-85, 2017.

[24] Chu, T. C., Ranson, W. F., \& Sutton, M. A., Applications of digital-image-correlation techniques to experimental mechanics, Experimental mechanics, 25(3), 232-244, 1985. 
